\title{
Extracellular Synthesis of Zinc Oxide Nanoparticles Using Thermo-Halotolerant Aeribacillus pallidus strain SJP 27: Characterization and Antibacterial Potential
}

\author{
Jagdish Parihar, Ashok Kumawat, Kamakhya Prakash Misra, Ashima Bagaria* \\ Department of Physics, Manipal University Jaipur, Jaipur-303007, Rajasthan, India
}

(Received 10 January 2021; revised manuscript received 23 March 2021; published online 09 April 2021)

\begin{abstract}
The current work reports the extracellular synthesis of zinc oxide ( $\mathrm{ZnO}$ ) nanoparticles (NPs) using the bacterial isolate Aeribacillus pallidus strain SJP 27 (Accession No. MW148443) from soil sample of arid and semi-arid regions of the Great Indian Thar desert. Bacterial cells were grown overnight at $60{ }^{\circ} \mathrm{C}$ incorporating a halo-tolerance of $5 \% \mathrm{w} / \mathrm{v} \mathrm{NaCl}$. Physiochemical characterization of $\mathrm{ZnO}$ NPs were carried out using UV-Visible spectroscopy (UV-Vis), Fourier transform infrared spectroscopy (FTIR) and Scanning electron microscopy (SEM). The antimicrobial activity of synthesized ZnO NPs was confirmed by minimum inhibitory concentration (MIC) against Escherichia coli $(8 \mathrm{mg} / \mathrm{ml})$ and Staphylococcus aureus $(4 \mathrm{mg} / \mathrm{ml})$. The present study encourages the use of bacterial isolates for the extracellular synthesis of ZnO NPs. To the best of our knowledge, this is the first ever reported study of a thermo-halotolerant, Aeribacillus pallidus for extracellular synthesis of $\mathrm{ZnO} \mathrm{NPs}$ in particular.
\end{abstract}

Keywords: Aeribacillus pallidus, Thermo halotolerant, Zinc oxide nanoparticles, FTIR, Energy band gap and extracellular synthesis.

DOI: 10.21272/jnep.13(2).02007

PACS numbers: 78.67.Bf, 33.20.Ea

\section{INTRODUCTION}

Over the last decade, nanotechnology has revolutionized every field of applied sciences [1]. In recent times, the process of green synthesis has further emerged as an alternate to physical and chemical methods of synthesis and has received recognition due to its ecofriendly nature [2]. $\mathrm{ZnO}$ being a biocompatible material, has attracted a significant attention not only of materials researchers, but of the nanobiotechnologists as well. Variety of applications like antimicrobial, anti-cancer, bioremediation, biomineralization, bioleaching, and biocorrosion etc. of zinc oxide nanoparticles (NPs) derived by extracellular methods have been reported [3-5]. There is limited evidence of effective $\mathrm{ZnO}$ nanoparticle synthesis using plants and microbes. Among methods of microbial synthesis, two main types can be identified intra- and extracellular methods. Intracellular production involves bacteria biomass for the nanocomposite formation, while the extracellular approach excludes microbial cells and uses supernatant rich in biologically active compounds that acts as a strong reducing agent [6]. Green synthesis of NPs from plant source has gained momentum in the recent past. But not allnatural products are non-toxic and even some microorganisms are pathogenic, which constitute the biggest disadvantage for such methods. Microbial agents contain certain enzymes and small molecule that tend to reduce the metal ions into metal NPs. However only a few microbes have the potential to synthesize ZnO NPs. More potential microbes for the synthesis of $\mathrm{ZnO}$ NPs must therefore be explored.

In the present study, we have demonstrated the use of the supernatant culture of Aeribacillus pallidus for the synthesis of $\mathrm{ZnO}$ NPs. Aeribacillus pallidus are gram positive rods, aerobic, motile and endospore forming bacteria, which grow at high temperature of $60^{\circ} \mathrm{C}$ and a salt tolerance of $5 \%(\mathrm{w} / \mathrm{v})$. This strain also produces innovative exopolysaccharides and flagellin protein that has various advantages $[7,8]$.

\section{METHODOLOGY}

\subsection{Sampling, Isolation and Molecular Identification of Bacterial Strain}

The bacterial strain, samples were collected from the arid and semi-arid regions of Western India. The samples were quickly transferred to the laboratory for isolation and identification of the bacterial strain. Standard protocols were used for isolation of the strains.

\subsection{Study of Phenotypic and Biochemical Characterization of the Strain SJP 27}

The suspensions of the soil samples were inoculated on nutrient agar (NA), Luria-Bertani broth (LB) by streaking and were incubated overnight at different temperatures. The bacterial strains were then isolated from the soil samples. Basic biochemical tests were performed like Grams staining, shape, colour, endospore, motility test, starch hydrolysis, casein hydrolysis, citrase utilization, indole test, catalase and deaminase test. To test for thermo-halotolerance, growth was tested over temperatures as high as $65^{\circ} \mathrm{C}$ and a salt concentration up to $5 \% \mathrm{w} / \mathrm{v} \mathrm{NaCl}$ [9].

\subsection{S rRNA Gene Amplification, Sequencing and Phylogenetic Analysis}

The molecular characterization of the bacterial isolate SJP27 was carried out using 16S rRNA. DNA was isolated from the pure isolated culture and its quality was evaluated on $1.2 \%$ Agarose Gel; a single band of high-molecular weight DNA has been observed. Frag-

\footnotetext{
* ashima.bagaria@jaipur.manipal.edu

The results were presented at the International Conference on Multifunctional Nanomaterials (ICMN2020)
} 
ment of $16 \mathrm{~S}$ rDNA gene was amplified by $27 \mathrm{~F}$ and 1492R primers. A single discrete PCR amplicon band of approximately $1500 \mathrm{bp}$ was observed when resolved on agarose gel. Forward and reverse DNA sequencing reaction of PCR amplicon was carried out with forward primer and reverse primers using BDT v3.1 Cycle sequencing kit on ABI 3730xl Genetic Analyzer. Consensus sequence of $16 \mathrm{~S}$ rDNA gene was generated from forward and reverse sequence data using aligner software. The $16 \mathrm{~S}$ rDNA gene sequence was used to carry out BLAST with the database of NCBI GenBank database[10]. Based on maximum identity score first ten sequences were selected and aligned using multiple alignment software program ClustalW. Distance matrix was generated and the phylogenetic tree was constructed using MEGA 7 [11].

\subsection{Phylogenetic Analysis}

The evolutionary history was inferred by using the Maximum Likelihood method based on the Kimura 2parameter model [12]. The bootstrap consensus tree inferred from 1000 replicates is taken to represent the evolutionary history of the taxa analyzed [13]. Branches corresponding to partitions reproduced in less than $50 \%$ bootstrap replicates are collapsed. The percentage of replicate trees in which the associated taxa clustered together in the bootstrap test (1000 replicates) are shown next to the branches. Initial tree(s) for the heuristic search were obtained automatically by applying Neighbor-Join and BioNJ algorithms to a matrix of pairwise distances estimated using the Maximum Composite Likelihood (MCL) approach, and then selecting the topology with superior log likelihood value. The analysis involved 11 nucleotide sequences. Codon positions included were 1 st $+2 \mathrm{nd}+3 \mathrm{rd}+$ Noncoding. All positions containing gaps and missing data were eliminated. There were a total of 1445 positions in the final dataset. Evolutionary analyses were conducted in MEGA7 [11].

\subsection{Synthesis of ZnO NPs and Optimization}

The selected bacterial isolates were grown in laboratory condition in $500 \mathrm{ml}$ Erlenmeyer flasks containing $100 \mathrm{ml} \mathrm{LB}$ medium and incubated in rotatory shaker overnight, with $120 \mathrm{rpm}$ at a temperature of $60^{\circ} \mathrm{C}$ and $65 \%$ humidity for $24 \mathrm{~h}$ to collect the cell free supernatant of bacteria for extra cellular biosynthesis of $\mathrm{ZnO}$ NPs. The supernatant was collected by centrifugation at $10000 \mathrm{rpm}$ for $10 \mathrm{~min}$. $100 \mathrm{ml}$ of Zinc acetate solution $(1 \mathrm{mM})$ was mixed with cell free supernatant and a rigorous magnetic stirring was performed at room temperature for $24 \mathrm{~h}$. The synthesis was monitored for a change in the color of the culture medium by visual inspection. The aqueous culture solution was further kept for drying in oven at $80^{\circ} \mathrm{C}$. The dried sample was crushed in sterile mortar until it was smooth and uniform. Annealing of dried sample was done at $700{ }^{\circ} \mathrm{C}$ for $5 \mathrm{~h}$. The dried sample powder was kept in a desiccator at room temperature for further analysis [6]. We have taken control as $\mathrm{ZnO}$ nanoparticles which is prepared by chemical method and biosynthesized NPs as the test sample which is obtained by Aeribacillus pallidus SJP 27 bacterial strain (thermo halotolerant).

\subsection{Characterization of $\mathrm{ZnO}$ NPs}

The transmittance spectra of the resultant $\mathrm{ZnO}$ NPs were analyzed using a UV-Vis spectrophotometer (Shimadzu UV2600) with a wavelength ranges from 320-480 nm. The chemical composition of $\mathrm{ZnO}$ NPs, and SJP 27 treated $\mathrm{ZnO}$ NPs were studied by FTIR examination. The $\mathrm{ZnO}$ NPs and SJP 27 treated with $\mathrm{ZnO}$ NPs was finely ground and dispersed in double distilled water before performing the FTIR analysis. The FTIR spectrum was recorded in $2000-500 \mathrm{~cm}^{-1}$ range using FTIR system (Bruker alpha). Field Emission Scanning electron microscopy (FESEM) (JEOL $7610 \mathrm{~F}$ Plus) was used to image and evaluate the morphology and size of the ZnO NPs.

\subsection{Evaluation of Antibacterial Activity of Biosynthesized ZnO NPs (MIC)}

The bacterial strains were cultured on Luria Bertani (LB) broth and stored at $-80^{\circ} \mathrm{C}$ in $30 \%$ glycerol. The minimal inhibitory concentration (MIC) of $\mathrm{ZnO}$ and biosynthesized NPs was determined against Grampositive (S. aureus) and Gram-negative bacteria (E. coli) by disc diffusion method. Positive and negative controls were included as well.

\section{RESULTS AND DISCUSSION}

\subsection{Biochemical and Morphological Characterization of Bacterial Strain SJP 27}

The isolated bacteria identified as SJP 27 were grown on nutrient agar (NA) and Luria-Bertani broth (LB). The bacterial isolates were Grams positive rods, aerobic, endospore forming, motile and cream in color. All the essential biochemical tests were performed, and the strain was tested negative for amylase, caseinase and citrase activity but showed activity for tryptophanase, catalase and deaminase. The $\mathrm{G}+\mathrm{C}$ content of the strain was $56 \%$. The bacterial growth was determined at various temperatures viz. 37, 45, 50, 60 and $65^{\circ} \mathrm{C}$ and an optimum temperature of $60^{\circ} \mathrm{C}$ for bacterial growth was achieved. The salt, sodium chloride $(\mathrm{NaCl})$, concentration was tested from $0-5 \%(\mathrm{w} / \mathrm{v})$ on nutrient agar plates. The optimum $\mathrm{pH}$ range for growth was also determined.

\subsection{Molecular Characterization of Bacterial Strain SJP 27}

The extraction of genomic DNA of isolated pure cultures from soil sample SJP 27 was carried out and quality was checked on $1.2 \%$ agarose gel. A single band of high-molecular weight DNA was observed. Isolated DNA from pure culture SJP 27, was amplified with 16S rRNA Specific Primer (8Fand 1492R) using Veriti ${ }^{\circledR} 96$ well Thermal Cycler (Model No. 9902). Single discrete band of $1445 \mathrm{bp}$ on $1.2 \%$ agarose gel was observed and shown in Fig. 1. 


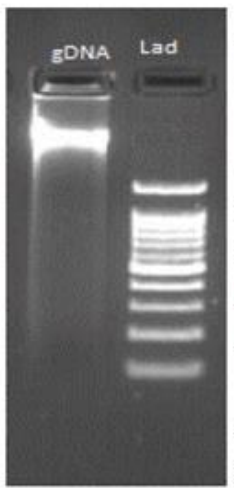

(a)

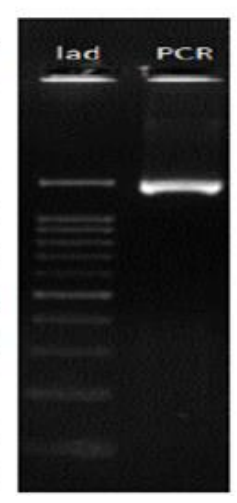

(b)

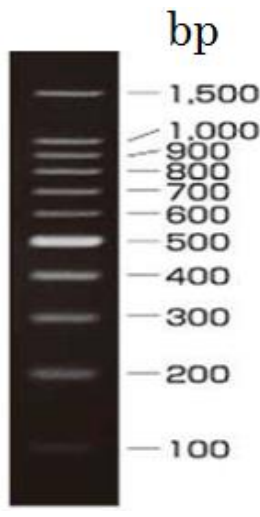

(c)
Fig. 1 - (a) genomic DNA, (b) 16s DNA amplicon, and (c) DNA ladder

\subsection{Phylogenetic analysis}

Phylogenetic analysis was carried out using neighbour joining method and SJP 27 showed $98 \%$ similarity with Aeribacillus pallidus, strain: DSM 3670T based on nucleotide homology (Fig. 2), Contributing towards the research on Aeribacillus pallidus, which is isolated mainly from hot water springs, deserts, marsh lands and lands contaminated from industrial wastewater $[14,15]$. The $16 \mathrm{~S}$ rDNA sequence isolated from SJP 27 was submitted to NCBI (MW148443).

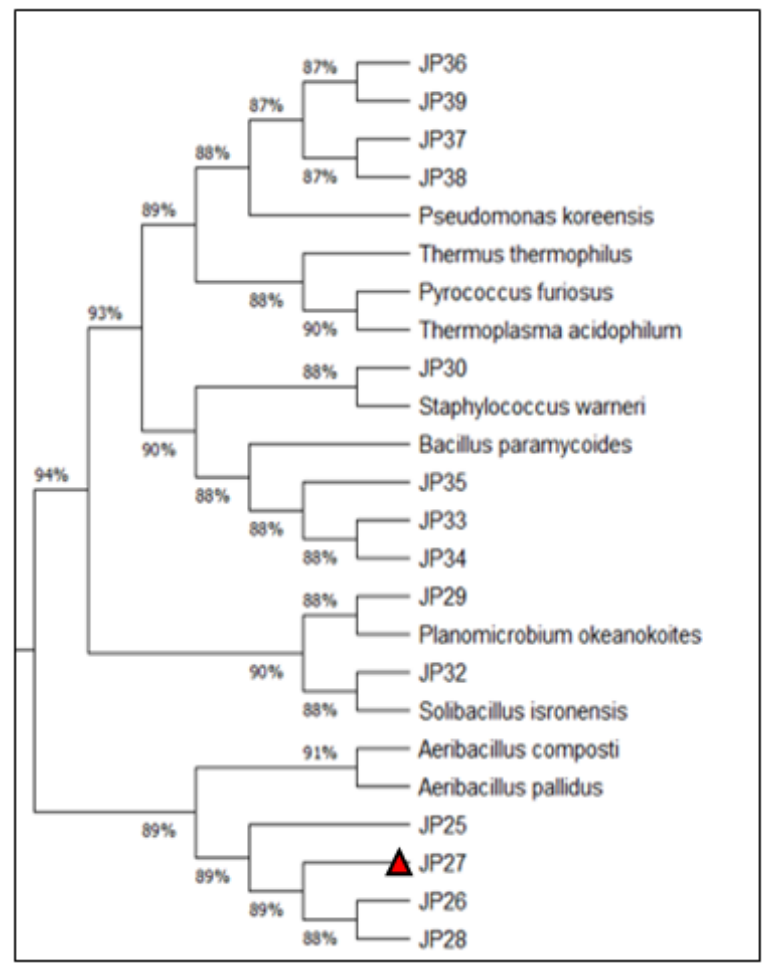

Fig. 2 - Evolutionary relationship based on 16S rDNA gene sequences. Strain SJP 27 (MW148443) is indicated by red triangle

\subsection{FTIR Spectra}

FTIR offers an impression to the vibrational and rotational modes of the existing molecules in the samples.
It is also helping to identify the functional groups possible in the reduction and stabilization of ZnO NPs. The FTIR spectra of controls ( $\mathrm{ZnO})$ and SJP 27 are shown in Fig. 3. The control $(\mathrm{ZnO})$ sample has a clear absorption band at $543 \mathrm{~cm}^{-1}$ which corresponds to the stretching of $\mathrm{Zn}-\mathrm{O}$ bond in the tetrahedral coordination [16]. This confirms the formation of $\mathrm{ZnO}$. Other absorption bands are also visible at $602,1031,1330,1407,1466,1525$ and $1693 \mathrm{~cm}^{-1}$ in Fig. 3. The feeble bands close to $600 \mathrm{~cm}^{-1}$ are generally assigned to the stretching vibrations of $\mathrm{Zn}-\mathrm{O}$ bonds in octahedral coordination. Remaining other absorption bands are correlated to the different vibrational states of carbon-based bonds. It is reported that $\mathrm{C}=\mathrm{C}$ stretching, $\mathrm{C}-\mathrm{O}$ stretching, $\mathrm{COO}-\mathrm{Zn}, \mathrm{C}=\mathrm{O}$ bond respectively give rise to the absorption bands at 1030, 1407, 1466, 1525 and $1693 \mathrm{~cm}^{-1}$. As the control $(\mathrm{ZnO})$ samples synthesis is via the route of different organic vehicles like ethanol and propanol and zinc acetate precursor, the presence of such carbon-based absorption bands is plausible. SJP 27 sample notices a reduction in the strength of each absorption band as compared to the control $(\mathrm{ZnO})$ sample. Reduction of the band at $543 \mathrm{~cm}^{-1}$ and slight rise at $602 \mathrm{~cm}^{-1}$ indicate that $\mathrm{ZnO}$ tetrahedral coordination weakens and the octahedral one strengthens due to the involvement of bacterial strain with the synthesis of $\mathrm{ZnO}$. Another, absorption band assigned to COO-Zn bond also observes a strong reduction due to bacterial infusion. Here it can be concluded that bacterial strain affects the $\mathrm{Zn}$ based bonds significantly in NPs.

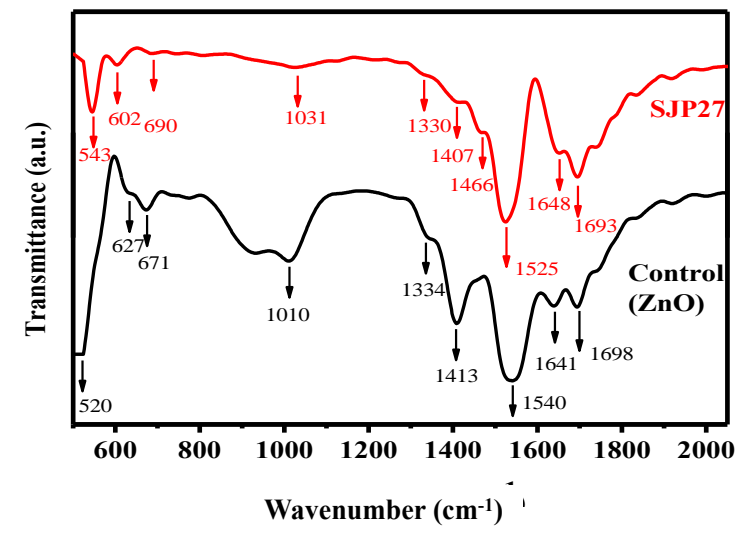

Fig. 3 - FTIR spectra of $\mathrm{ZnO}$ synthesized through chemical and bio-route respectively

\subsection{UV-Visible Spectra}

UV-Vis transmittance spectra as presented in Fig. 4 shows a clear red shift in the absorption dip, from control $(\mathrm{ZnO})$ to SJP 27. The control ( $\mathrm{ZnO})$ sample has absorption dip at $373 \mathrm{~nm}(3.324 \mathrm{eV})$ which occurs due to the band-to-band transition indicating the corresponding energy to be the band gap. The bacterial strain has been found to reduce the band gap to $3.245 \mathrm{eV}(383 \mathrm{~nm})$ eventually triggering a red-shift of the absorption dip. It will be discussed in the further section of FESEM that the particle size enhances due to the inclusion of bacterial strain in the synthesis process. The quantum confinement effects establish a fact that reduction of particle size causes a blue shift of the band gap in $\mathrm{ZnO}$ [17]. Here, reverse is happening, so 
the red shift is justified following the identical reason of a quantum confinement effects.

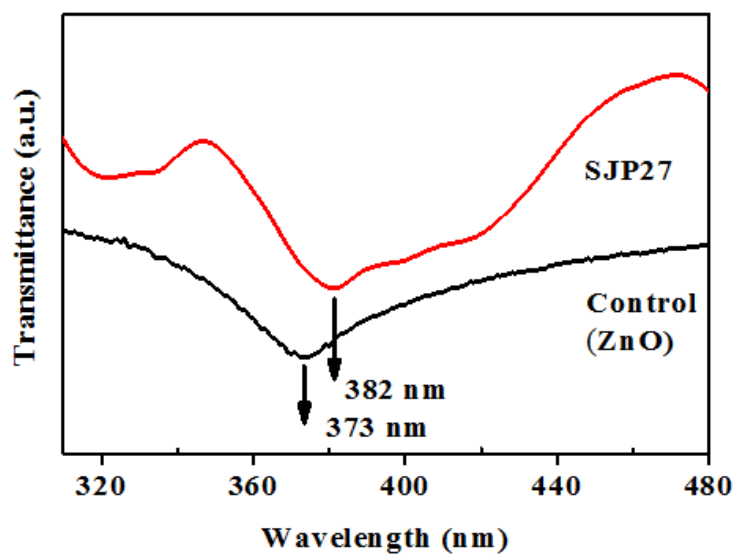

Fig. 4 - (a) and (b) transmittance spectra of $\mathrm{ZnO}$ synthesized through chemical and biosynthesis, respectively
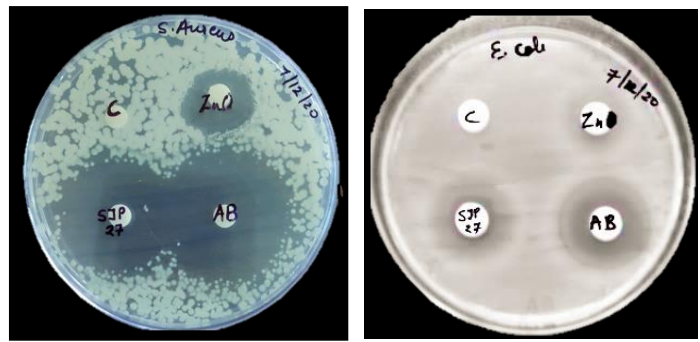

Fig. 5 - Antimicrobial activity of control $(\mathrm{ZnO})$ and biosynthesized SJP 27, respectively
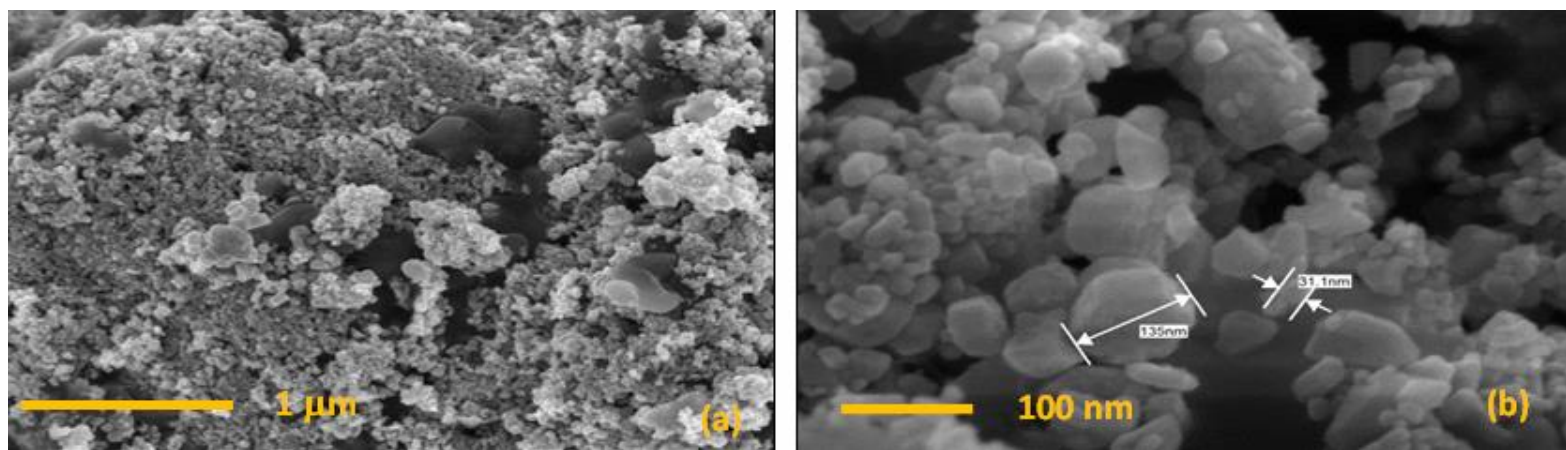

Fig. 6 - SEM micrographs: (a), (b) $\mathrm{ZnO}$ synthesized through chemical route
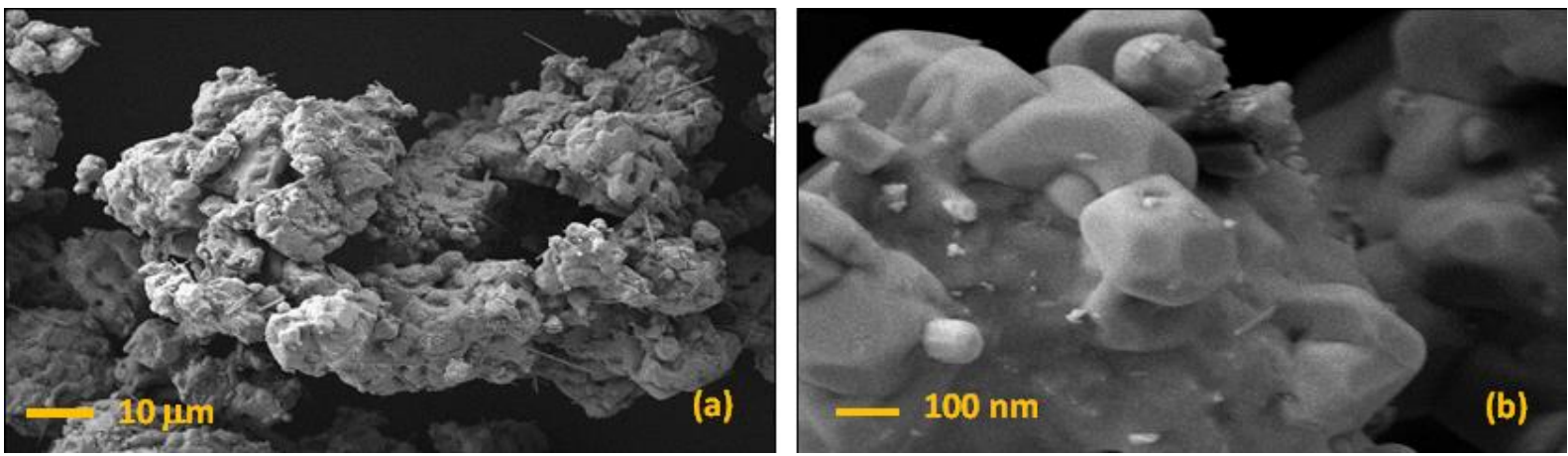

Fig. 7 - SEM micrographs: (a), (b) ZnO synthesized through biosynthesis route 


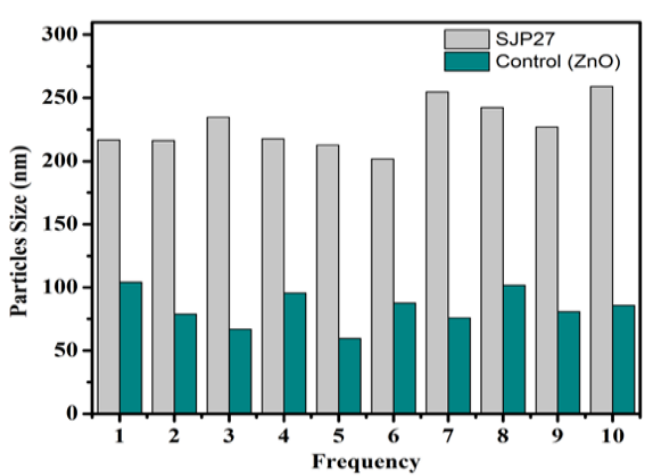

Fig. 8 - Size distribution of control (ZnO) and SJP 27 NPs

strain SJP 27 in the size ranges from $200 \mathrm{~nm}$ to $262 \mathrm{~nm}$. The synthesized NPs from bacterial strain are biologically active against the tested Grams positive and Grams negative strains. Therefore, our findings encourage to isolate and screen unexplored thermo- philes, which could be considered for utilization in the biosynthesis of NPs for various potential biotechnological applications.

\section{ACKNOWLEDGEMENTS}

This research is financially supported from Department of Science and Technology, Rajasthan, India Ref: P. 7(3) DST/ B T R\& D/ E A C/ 2018 / 3145 and Enhanced Seed Grant through Endowment, Manipal University Jaipur, Rajasthan India. Ref: EF/ 2017-18/ QE 04-01. Jagdish Parihar thanks Manipal University Jaipur for Enhanced PhD Scholarship Ref: EF/ 201718/ QE 02-11. The authors are thankful to Central Analytical Facility.

Lab, Manipal University, Jaipur, for carrying out various characterization techniques like UV, FTIR. We are very obliged to Sophisticated Analytical Instrument Facility (SAIF), Manipal University Jaipur for FESEM measurement.

\title{
REFERENCES
}

1. N.A. Al-Dhabi, M. Valan Arasu, Nanomaterials 8 No 7, 500 (2018).

2. S.A. Ojo, A. Lateef, M.A. Azeez, S.M. Oladejo, A.S. Akinwale, T.B. Asafa, IEEE Transact. Nanobiosci. 15 No 5,433 (2016).

3. L. Wang, C. Hu, L. Shao, Int. J. Nananomed. 12, 1227 (2017).

4. H.M. Yusof, R. Mohamad, U.H. Zaidan, J. Animal Sci. Biotechnol. 10 No 1, 57 (2019).

5. S. Keerthana, A. Kumar, Critical Rev. Toxicology 50 No 1, 47 (2020).

6. S. Rehman, B. Rabindran Jermy, S. Akhtar, J. Francis Borgio, S.A. Azeez, V. Ravinayagam, R.Al Jindan, Z.H. Alsalem, A. Buhameid, Ad. Gani, Artificial Cells, Nanomed. Biotechnol. 47 No 1, 2072 (2019).

7. N. Radchenkova, I. Boyadzhieva, N. Atanasova, An. Poli, I. Finore, P.Di Donato, B. Nicolaus, I. Panchev, M. Kuncheva, M. Kambourova, J. Appl. Microbiol. 119 No 5, 1301 (2015).

8. C. Zheng, Z Li, J Su, R Zhang, C Liu, M Zhao, J. Appl. Microbiol. 113 No 1, 44 (2012).

9. J.G. Holt, N.R. Krieg, P.H. Sneath, Bergey's manual of determinative bacterology (1994).

10. S.-H. Yoon, et al., Int. J. Systemat. Evolut. Microbiol. 67 No 5,1613 (2017).

11. S. Kumar, G. Stecher, K. Tamura, Molecular Biol. Evolut. 33 No 7,1870 (2016).

12. M. Kimura, J. Molecular Evolut. 16 No 2, 111 (1980).

13. J. Felsenstein, Evolution 39 No 4783 (1985).

14. S. Mechri, M.B.E. Berrouina, M.O. Benmrad, N.Z. Jaouadi, H. Rekika, E. Moujehed. A. Chebbi, S. Sayadi, M. Chamkha, S. Bejara, B. Jaouadia, Int. J. Biol. Macromolec. 94221 (2017).

15. H. Bose, T. Satyanarayana, Bioproc. Biosyst. Eng. 39 No 10, 1515 (2016).

16. A. Kumawat, et al., Solid State Sci. 108, 106379 (2020).

17. S. Repp, E. Erdem, Spectrochim. Acta Part A: Molec. Biomolec. Spectrosc. 152, 637 (2016).

18. S. Busi, et al., J. Microbiol. Biotechnol. Food Sci. 9 No 5 , 407 (2020).

\section{Позаклітинний синтез наночастинок оксиду цинку з використанням термогалотолерантного штаму Aeribacillus pallidus SJP 27: Характеристика та антибактеріальний потенціал}

\author{
Jagdish Parihar, Ashok Kumawat, Kamakhya Prakash Misra, Ashima Bagaria \\ Department of Physics, Manipal University Jaipur, Jaipur 303007, Rajasthan, India
}

\begin{abstract}
В роботі повідомляється про позаклітинний синтез наночастинок (NPs) оксиду цинку (ZnO) з використанням бактеріального ізоляту Aeribacillus pallidus штаму SJP 27 (обліковий номер MW148443) із зразка ґрунту посушливих і напівпосушливих районів великої індійської пустелі Тар. Бактеріальні клітини вирощували протягом ночі при $60^{\circ} \mathrm{C}$, включаючи галотолерантність $5 \% \mathrm{w} / \mathrm{v} \mathrm{NaCl}$. Фізикохімічні характеристики ZnO NPs вивчалися за допомогою УФ-видимої спектроскопії (UV-Vis), iнфpaчервоної спектроскопії з перетворенням Фур'є (FTIR) та скануючої електронної мікроскопії (SEM). Антимікробна активність синтезованих ZnO NPs була підтверджена мінімальною інгібуючою концентрацією кишкової палички Escherichia coli (8 мг/мл) та золотистого стафілокока Staphylococcus aureus (4 мг/мл). Це дослідження стимулюе використання бактеріальних ізолятів для позаклітинного синтезу ZnO NPs. Наскільки нам відомо, це перше з коли-небудь опублікованих досліджень термогалотолеранту Aeribacillus pallidus для позаклітинного синтезу, зокрема, ZnO NPs.
\end{abstract}

Ключові слова: Aeribacillus pallidus, Термогалотолерантний, Наночастинки оксиду цинку, FTIR, Ширина забороненої зони, Позаклітинний синтез. 